06.12.2019 № 361-IX. URL: https://zakon.rada.gov.ua/laws/show/361-20 (дата звернення: 05.04.2021).

5. Про ратифікацію Конвенції Ради Європи про відмивання, пошук, арешт та конфіскацію доходів, одержаних злочинним шляхом, та про фінансування тероризму: Закон України від 17.11.2010 № 2698-VI. URL: https://zakon.rada.gov.ua/laws/show/2698-17 (дата звернення: 05.04.2021).

6. Кримінальний процесуальний кодекс України: Закон України від 13.04.2012 № 4651-VI. URL: https://zakon.rada.gov.ua/laws/show/4651-17 (дата звернення: 05.04.2021).

7. Красноборов О. Ретроспектива законодавчого регулювання кримінальної відповідальності за легалізацію (відмивання) майна, одержаного злочинним шляхом. Підприємництво, господарство i право. 2020. № 12. C. 202-206. URL: http://pgp-journal.kiev.ua/archive/ 2020/12/36.pdf (дата звернення: 05.04.2021).

DOI https://doi.org/10.30525/978-9934-26-074-2-50

\title{
КРИМІНАЛЬНА ВІДПОВІДАЛЬНІСТЬ ЗА ВЧИНЕННЯ АКТІВ НЕЗАКОННОГО ВТРУЧАННЯ В ДІЯЛЬНІСТЬ ЦИВІЛЬНОЇ АВІАЦІЇ
}

\author{
Кундеус В. Г. \\ кандидат юридичних наук, доцент, \\ доцент кафедри кримінального права та кримінології \\ факультету № 6 \\ Харківського національного університету внутрішніх справ \\ м. Харків, Україна
}

В сучасному стані розвитку авіаційного транспорту акти незаконного втручання в діяльність цивільної авіації (далі - акти незаконного втручання) $є$ найбільш небезпечними посяганнями на безпеку авіаційного транспорту. Визначення кола актів незаконного втручання регламентуються міжнародними конвенціями, учасником яких є Україна: Конвенція про злочини та деякі інші акти, що вчинюються на борту повітряних суден від 14.09.1963 року, Конвенція про боротьбу з незаконним захопленням повітряних суден від 16.12.1970 року, Конвенція про боротьбу з незаконними актами, спрямованими проти безпеки цивільної авіації від 23.09.1971 року, Додаток 17 до Конвенції про 
міжнародну цивільну авіацію 1944 року «Безпека. Захист міжнародної цивільної авіації від актів незаконного втручання», Керівництво 3 авіаційної безпеки (Doc 8973), а також іншими міжнародними актами та актами законодавства України.

Глава 1 Додатку 17 «Безпека: захист міжнародної цивільної авіації від актів незаконного втручання» до Конвенції про міжнародну цивільну авіацію 1944 року дає визначення акту незаконного втручання як акту або спроби його, що створює загрозу безпеці цивільної авіації і включає: 1) незаконне захоплення повітряних суден; 2) руйнування повітряного судна, що перебуває в експлуатації; 3) захоплення заручників на борту повітряних суден або на аеродромах; 4) насильницьке проникнення на борт повітряного судна, в аеропорт або в розташування аеронавігаційного засобу чи служби; 5) розміщення на борту повітряного судна або в аеропорту зброї, небезпечного пристрою або матеріалу, призначених для досягнення злочинних цілей; 6) використання повітряного судна, що перебуває в експлуатації, з метою заподіяння каліцтва, інших ушкоджень здоров’ю, смерті фізичній особі або значної шкоди майну чи навколишньому природному середовищу; 7) повідомлення навмисно неправдивої інформації, що ставить під загрозу безпеку повітряного судна під час польоту або на землі, безпеку пасажирів, членів екіпажу, наземного персоналу, інших осіб в аеропорту чи в розташуванні засобів або підрозділу цивільної авіації (переклад наш - В.К.) [1]. Конвенція про боротьбу з незаконними актами по відношенню до міжнародної цивільної авіації від 10 вересня 2010 року уточнює перелік таких актів і додатково криміналізує замах, погрозу, організацію чи допомогу (співучасть) вчинення незаконних актів по відношенню до міжнародної цивільної авіації [2].

Стаття 1 Конвенції про боротьбу 3 незаконними актами, спрямованими проти безпеки цивільної авіації від 23.09.1971 року визнає акти проти безпеки цивільної авіації злочином у випадку, якщо особа незаконно і навмисно: а) скоює акт насильства відносно особи, що перебуває на борту повітряного судна у польоті, якщо такий акт може загрожувати безпеці цього повітряного судна; b) руйнує повітряне судно, що перебуває в експлуатації, або заподіює цьому повітряному судну пошкодження, яке виводить його з ладу або може загрожувати його безпеці у польоті; с) розміщує або вчиняє дії, що приводять до розміщення на повітряному судні, що перебуває в експлуатації, будь-яким способом пристрій або речовину, яка виводить його 3 ладу, або спричиняє йому пошкодження, яке може загрожувати його безпеці у польоті; d) руйнує або пошкоджує аеронавігаційне обладнання або втручається в його експлуатацію, якщо такий акт може загрожувати 
безпеці повітряних судів у польоті; е) повідомляє завідомо недостовірні відомості, створюючи тим самим загрозу безпеки повітряного судна у польоті (переклад наш - В.К.) [3].

Визначення актів незаконного втручання передбачено національним законодавством. Зокрема, ст. 86 Повітряного кодексу України [4] та п.п. 6) п. 2 Розділу II Державної програми авіаційної безпеки цивільної авіації від 21.03.2017 року [5] визначають акт незаконного втручання та включають до них ті самі дії, що визначені Додатком 17 Конвенції про міжнародну цивільну авіацію 1944 року.

Слід вказати, що у правовій доктрині не визначено повного переліку актів незаконного втручання в діяльність цивільної авіації. Залишається неоднозначним визначення цього поняття. На наш погляд, найбільш повне визначення поняття «акти незаконного втручання в діяльність цивільної авіації» дає А.В. Філіппов, який пропонує визначити акти незаконного втручання як навмисні злочинні дії, а також погроза, спроба, організація, участь, допомога, змова чи сприяння щодо таких дій, спрямовані проти безпеки цивільної авіації та авіаційних об'єктів, які призвели або створили реальну загрозу настання тяжких наслідків, таких як загибель або тяжке чи середньої тяжкості тілесне ушкодження людині, значні майнові збитки, угон, захоплення, викрадення чи пограбування повітряного судна, або втрата законним експлуатантом контролю над повітряним судном іншим чином [6, с. 246].

Згідно ч. 3 ст. 3 Кримінального кодексу України (далі- КК) кримінальна протиправність діяння, а також його караність та інші кримінально-правові наслідки визначаються тільки цим Кодексом. Частина 2 ст. 1 КК вказує, що КК визначає, які суспільно небезпечні діяння є кримінальними правопорушеннями та які покарання застосовуються до осіб, що їх вчинили [7]. 3 урахуванням визначених міжнародним та національним законодавством видів актів незаконного втручання, кримінальна відповідальність передбачена за: незаконне захоплення повітряних суден ст. 278 КК «Угон або захоплення залізничного рухомого складу, повітряного, морського чи річкового судна»; захоплення заручників на борту повітряних суден або на аеродромах - ст. 147 КК «Захоплення заручників»; руйнування повітряного судна, що перебуває в експлуатації - ст. 277 КК «Пошкодження шляхів сполучення і транспортних засобів»; насильницьке проникнення на борт повітряного судна, в аеропорт або в розташування аеронавігаційного засобу чи служби ст. 296 КК «Хуліганство», ст. 257 «Бандитизм» тощо; розміщення на борту повітряного судна або в аеропорту зброї, небезпечного пристрою або матеріалу, призначених для досягнення злочинної мети - ст. 263 КК «Незаконне поводження зі зброєю, бойовими припасами або 
вибуховими речовинами», ст. 265 КК «Незаконне поводження з радіоактивними матеріалами», ст. 267 КК «Порушення правил поводження 3 вибуховими, легкозаймистими та їдкими речовинами або радіоактивними матеріалами», ст. 269 КК «Незаконне перевезення на повітряному судні вибухових або легкозаймистих речовин» тощо; використання повітряного судна, що перебуває в експлуатації, з метою заподіяння каліцтва, інших ушкоджень здоров'ю, смерті фізичній особі або значної шкоди майну чи довкіллю - ст. 115 КК «Умисне вбивство», 258 КК «Терористичний акт» тощо; повідомлення навмисно неправдивої інформації, що ставить під загрозу безпеку повітряного судна під час польоту або на землі, безпеку пасажирів, членів екіпажу, наземного персоналу або громадськості в аеропорту чи в розташуванні засобів або підрозділу цивільної авіації - ст. 195 КК «Погроза знищення майна», ст. 259 КК «Завідомо неправдиве повідомлення про загрозу безпеці громадян, знищення чи пошкодження об'єктів власності» тощо.

Висновок. Дослідження нормативних характеристик актів незаконного втручання дозволяє стверджувати, що до них належать суспільно небезпечні, протиправні діяння, пов'язані з посяганням на нормальну діяльність цивільної авіації та авіаційних об'єктів, що визначені нормами міжнародного та національного законодавства як акти незаконного втручання в діяльність цивільної авіації.

Кримінальна відповідальності за вчинення актів незаконного втручання передбачена статтями Особливої частини КК, що розташовані у різних розділах КК залежно від їх родового об'єкту. Підставою кримінальної відповідальності за вчинення актів незаконного втручання в діяльність цивільної авіації $\epsilon$ наявність у діяннях особи складу кримінального правопорушення, передбаченого Кримінальним кодексом України.

\section{Література:}

1. Приложение 17 к Конвенции о международной гражданской авиации. Безопасность. Защита международной гражданской авиации от актов незаконного вмешательства // ИКАО. Издание десятое, апрель 2017 года. URL: http://www.caakz.com/wp-content/uploads/2020/03/prilozhenie-17.-bezopasnost.-zashhita-mezhdunarodnoj-grazhdanskoj-aviaczii-otaktov-nezakonnogo-vmeshatelstva.pdf (дата звернення: 12.04.2021).

2. Конвенція про боротьбу з незаконними актами по відношенню до міжнародної цивільної авіації від 10.09.2010 // База даних (БД) «Законодавство України» / ВР України. URL: https://zakon.rada.gov.ua/ laws/show/954_013\#Text (дата звернення: 12.04.2021). 
3. Конвенція про боротьбу з незаконними актами, спрямованими проти безпеки цивільної авіації від 23.09.1971 // БД «Законодавство України» / ВР України. URL: https://zakon.rada.gov.ua/laws/show/ 995_165\#Техt (дата звернення:12.04.2021).

4. Повітряний кодекс України: Закон України від 19.05.2011 № 3393-VI // БД «Законодавство України» / ВР України. URL: https://zakon.rada.gov.ua/laws/show/3393-17 (дата звернення: 12.04.2021).

5. Про Державну програму авіаційної безпеки цивільної авіації: Закон України; Програма від 21.03.2017 № 1965-VIII // БД «Законодавство України» / ВР України. URL: https://zakon.rada.gov.ua/laws/show/ 1965-19\#Text 17 (дата звернення: 12.04.2021).

6. Філіппов А.В. Поняття авіаційної безпеки: новели вітчизняного. та міжнародного права, проблеми гармонізації // Юридичний науковий електронний журнал. 3/2018. URL:http://lsej.org.ua/3_2018/70.pdf (дата звернення: 12.04.2021).

7. Кримінальний кодекс України: Закон України від 05.04.2001 № 2341-III // БД «Законодавство України» / Верховна Рада України. URL: https://zakon.rada.gov.ua/laws/show/2341-14 (дата звернення: 12.04.2021).

DOI https://doi.org/10.30525/978-9934-26-074-2-51

\title{
ТИПОЛОГІЗАЦІЯ ЖЕРТВ ЗЛОЧИНІВ: КРИМІНОЛОГІЧНИЙ АНАЛІЗ
}

\author{
Луценко I. Г. \\ кандидат юридичних наук, \\ доцент кафедри кримінального права та кримінології \\ факультету № 6 \\ Харківського начіонального університету внутрішніх справ \\ м. Харків, Украӥна
}

Питання про вивчення жертви злочину на сучасному етапі розвитку суспільних відносин носить досить актуальний характер. Віддаючи належне існуючим фундаментальним науковим дослідженням у зазначеній сфері, сучасним науковцям доводиться стикатися з новими викликами як кримінального світу так і загально цивілізаційних процесів, які породжують, провокують та живлять злочинність, що призводить до збільшення жертв злочинів. Це пов'язано із соціальною природою 